\title{
MJO Modulation of Station Rainfall in the Semiarid Seridó, Northeast Brazil
}

\author{
Cati E. A. Valadão1,2, Paulo S. Lucio', Rosane R. Chaves ${ }^{1}$, Leila M. V. Carvalho² \\ ${ }^{1}$ Programa de Pós-Graduação em Ciências Climáticas, Universidade Federal do Rio Grande do Norte, Natal, \\ Brazil \\ ${ }^{2}$ Earth Research Institute and Department of Geography, University of California, Santa Barbara, USA \\ Email: cati.valadao@gmail.com, cati.valadao@pq.cnpq.br
}

Received 11 April 2015; accepted 6 October 2015; published 9 October 2015

Copyright (C) 2015 by authors and Scientific Research Publishing Inc.

This work is licensed under the Creative Commons Attribution International License (CC BY).

http://creativecommons.org/licenses/by/4.0/

c) (†) Open Access

\section{Abstract}

The influence of the Madden Julian Oscillation (MJO) on station rainfall over the Seridó region of Rio Grande do Norte state, Northeast Brazil is examined based on 17 raingauge daily data over 30-year period (1 January-31 December, 1981-2010). The Seridó is one of the driest regions in Northeast Brazil and is recognized as particularly vulnerable to desertification by the United Nations Convention to Combat Desertification. Firstly, daily anomalies were calculated by removing the 30-year daily climatology. Then, to distinguish the MJO signal from other patterns of climate variability, the daily anomalies were band pass filtered in the frequency domain (20 - 90 days) by applying Fast Fourier Transform (FFT). Composites of rainfall anomalies were computed for each of the eight phases of the MJO during February-May (FMAM) rainy season, based on the JonesCarvalho MJO index. Only days classified as MJO events were considered in the composites. For each phase composite, statistical significance tests were computed independently at each individual station by applying a two-tailed Student's t-test at $5 \%$ significance level. Preliminary results showed that the rainfall anomalies have a spatial coherence throughout the MJO cycle. Extreme positive (negative) anomalies occurred in phase 2 (phase 5), where 13 (12) out of the 17 stations showed statistically significant anomalies in the range of $0.9-1.9 \mathrm{~mm} / \mathrm{day}(0.8-1.7 \mathrm{~mm} / \mathrm{day})$. The typical difference between the wet MJO phase 2 and dry phase 5 represented at least $50 \%$ modulation of the daily mean rainfall.

\section{Keywords}

Madden-Julian Oscillation, Intraseasonal, Raingauge 


\section{Introduction}

The tropical Brazil does not only encompasses the Earths's largest rain forest in the Amazon basin, but also the "Caatinga”, which is the dry forest in Northeast Brazil (NEB), occupying an area of around 800,000 Km² and covering approximately $11 \%$ of the national territory, as illustrated in Figure 1. The Caatinga is a fragile and unique ecosystem with a great variety of endemic species. Brazil's Northeast is the third largest, the third mostpopulous, and also one of the poorest regions in the country. The region is characterized by marked interannual precipitation variability, and has a long history of severe recurrent droughts, which seriously affect its agricultural production and water resources.

Given NEB's unique climatic characteristics and land degradation, the United Nations Convention to Combat Desertification (UNCCD, www.unccd.int) has recognized NEB as particularly vulnerable to desertification [1]. In this context, an area known as Seridó, located in the semiarid interior of Rio Grande do Norte state (RN), has been assessed to be one of the most affected by desertification in this state (see Figure 1 for location). This is due not only to its climatic conditions, but also to the human activities associated with inappropriate land management in the region. Land use patterns and practices in the Seridó have increased land degradation, associated with deforestation of the Caatinga to create fields and pastures, and to supply the demand of fuelwood for households, and for the production of wood charcoal for industries (e.g., ceramic, gypsum, plaster, limekilns). Salinization of soils and local water resources is another important factor of environmental degradation over the area [1]. Water supply in the Seridó is basically provided through dams, small reservoirs, wells and cisterns that collect water during the rainy season.

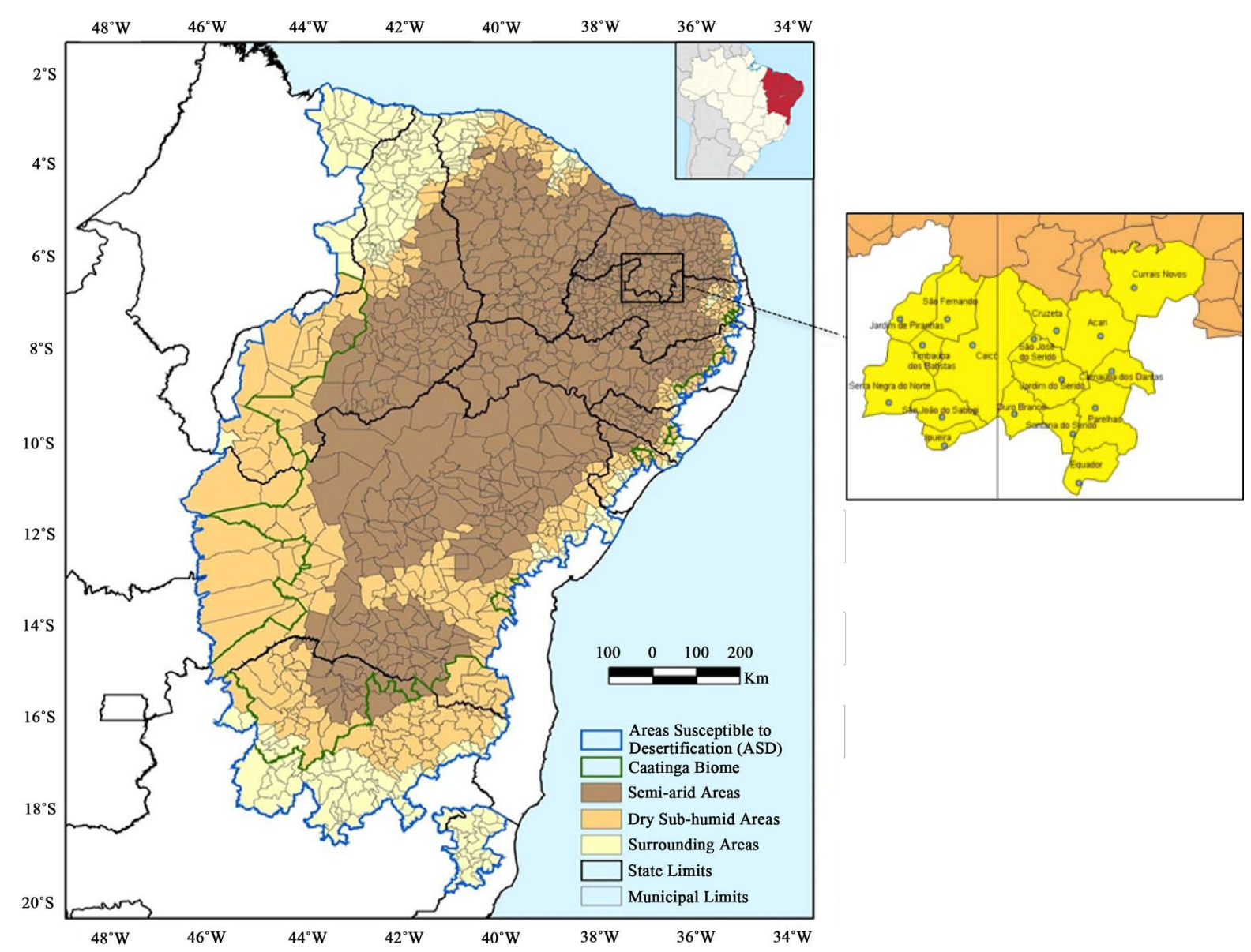

Figure 1. Areas susceptible to desertification according to the UNCCD, including the Caatinga biome area (see legend). The inset shows the location of Northeast Brazil (in red). The frame on the right side shows the study area: the Seridó of Rio Grande do Norte state. Dots represent the raingauge station location. Adapted from the National Action Program to Combat Desertification and Mitigate the Effects of Drought PAN-Brazil [1]. 
Precipitation over the Seridó is concentrated in a short wet season, which comprises several spells of heavy rains, each lasting on the order of a few days to a week or more, separated by breaks of reduced rainfall as illustrated in Figure 2. The Seridó experiences large fluctuations in annual rainfall: the year 2000 not only was wetter than 2001, but also showed spells of comparatively enhanced rainfall. Comparing with the annual climatology (see Table 1), the year 2000 showed wetter-than-normal conditions, whereas the year 2001 was drier-than-normal.

All these environmental impacts have contributed to increase social and economic impoverishment, and migration of people from rural areas. Given the importance of intraseasonal rainfall variations for agricultural production and water management in semiarid regions, this study focuses on the influence of the Madden-Julian Oscillation (MJO) over the environmental fragile Seridó/RN region.

\section{Background}

The MJO has been documented as a major source of variability in the tropics. The MJO consists of a large-scale region of enhanced convection and precipitation that originates over the tropical Indian Ocean and propagates slowly eastward to the western-central Pacific [2]-[5]. Many studies have revealed that the propagation and evolution of the MJO events have great influence on precipitation not only in the tropical region, but also in the extratropics. For instance, over South America [6]-[11], Africa [12] [13], Mexico [14], United States [15]-[18], Canada [19], Australia [20], Indonesia [21] [22], and China [23] [24]. The MJO also affects monsoon systems (e.g., [25]-[30]).

Previous studies using gridded station rainfall over tropical South America showed that the MJO plays an important role in modulating its convection and precipitation. For example, Carvalho et al. [7] found evidence of an increase on extreme rainfall events over north-northeastern Brazil (based on the December-February 95th daily rainfall percentile) during the MJO phase characterized by enhanced convective activity over the central

Table 1. Station Details. Code refers to the station code in Figure 3. Annual total rainfall is based on 30-year period from January-December 1981-2010. FMAM (February-May) corresponds to the rainy season mean total (in parentheses as a percentage of the annual total). Units are in $\mathrm{mm}$ for rainfall and $\mathrm{m}$ for altitude.

\begin{tabular}{|c|c|c|c|c|c|}
\hline Station name & Code & Location & Altitude & Annual total rainfall & FMAM (\%) \\
\hline Acari & Aca & $6.43^{\circ} \mathrm{S}, 36.63^{\circ} \mathrm{W}$ & 270 & 546 & $404(74)$ \\
\hline Caicó & Cai & $6.45^{\circ} \mathrm{S}, 37.08^{\circ} \mathrm{W}$ & 143 & 660 & $515(78)$ \\
\hline Carnaúba dos Dantas & CDa & $6.55^{\circ} \mathrm{S}, 36.58^{\circ} \mathrm{W}$ & 460 & 574 & $427(74)$ \\
\hline Cruzeta & Cru & $6.40^{\circ} \mathrm{S}, 36.78^{\circ} \mathrm{W}$ & 140 & 623 & $445(71)$ \\
\hline Currais Novos & CNo & $6.25^{\circ} \mathrm{S}, 36.52^{\circ} \mathrm{W}$ & 350 & 537 & 399 (74) \\
\hline Equador & Equ & $6.93^{\circ} \mathrm{S}, 36.72^{\circ} \mathrm{W}$ & 500 & 488 & $344(70)$ \\
\hline Ipueira & Ipu & $6.80^{\circ} \mathrm{S}, 37.18^{\circ} \mathrm{W}$ & 217 & 645 & 495 (77) \\
\hline Jardim de Piranhas & JPi & $6.37^{\circ} \mathrm{S}, 37.35^{\circ} \mathrm{W}$ & 130 & 664 & $514(77)$ \\
\hline Jardim do Seridó & JSe & $6.58^{\circ} \mathrm{S}, 36.77^{\circ} \mathrm{W}$ & 218 & 607 & $456(75)$ \\
\hline Ouro Branco & $\mathrm{OBr}$ & $6.70^{\circ} \mathrm{S}, 36.93^{\circ} \mathrm{W}$ & 195 & 599 & $461(77)$ \\
\hline Parelhas & Par & $6.68^{\circ} \mathrm{S}, 36.65^{\circ} \mathrm{W}$ & 325 & 571 & $436(76)$ \\
\hline Santana do Seridó & SSe & $6.77^{\circ} \mathrm{S}, 36.73^{\circ} \mathrm{W}$ & 336 & 577 & $430(75)$ \\
\hline São João do Sabugi & SJSa & $6.72^{\circ} \mathrm{S}, 37.20 \mathrm{~W}$ & 187 & 680 & $529(78)$ \\
\hline São Fernando & $\mathrm{SFe}$ & $6.37^{\circ} \mathrm{S}, 37.18^{\circ} \mathrm{W}$ & 139 & 663 & $503(76)$ \\
\hline Sã José do Seridó & SJSe & $6.43^{\circ} \mathrm{S}, 36.87^{\circ} \mathrm{W}$ & 207 & 605 & $449(74)$ \\
\hline Serra Negra do Norte & SNN & $6.65^{\circ} \mathrm{S}, 37.38^{\circ} \mathrm{W}$ & 180 & 799 & $605(76)$ \\
\hline Timbaúba dos Batistas & TBa & $6.45^{\circ} \mathrm{S}, 37.27^{\circ} \mathrm{W}$ & 161 & 705 & $551(78)$ \\
\hline
\end{tabular}



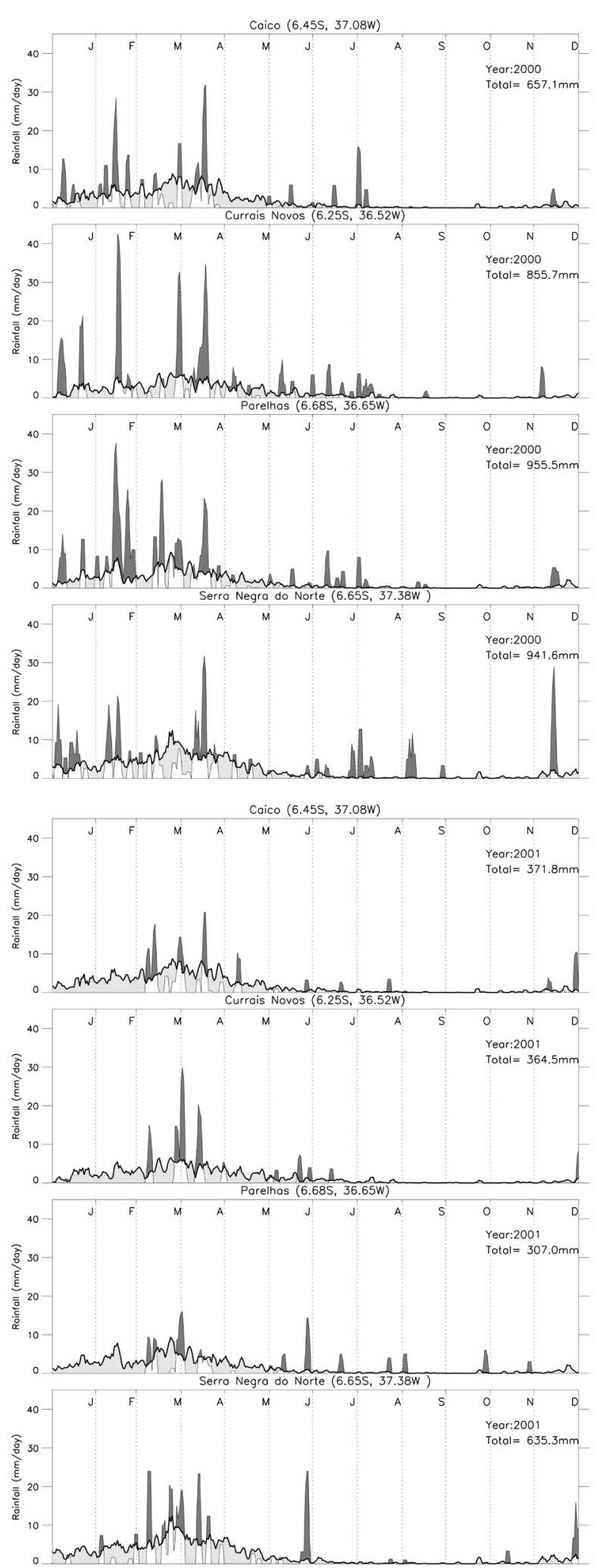

Figure 2. Time series of 3-day running-mean rainfall for four stations in the Seridó/RN for the period of 1 January to 31 December 2000 (top panel) and 2001 (bottom panel). Also shown are smoothed climatological annual cycles for each station, computed using all daily data from 1981 to 2010. Positive (negative) rainfall anomalies with respect to the smoothed climatology are dark (light) shaded. 
Pacific and suppression over the Maritime Continent. Opposite features were observed when the enhanced convection was over the Maritime Continent and suppression over the central Pacific. Souza et al. [31] examined precipitation variability over eastern Amazon and NEB during the autumn rainy season (March-May), combining the effects of the tropical Pacific and the Atlantic sea surface temperature (SST) anomalies in two extreme and contrasting scenarios. Their favorable (unfavorable) scenario was characterized by simultaneous occurrence of southward (northward) SST gradient in the intertropical Atlantic and La Niña (El Niño). They found evidence that, on intraseasonal timescale, anomalously deficient and abundant precipitation events occurred alternately in both extreme climatic scenarios. They suggested that the MJO played a key role in modulating deep convection and precipitation over the region during years under extreme climatic conditions. Souza and Ambrizzi [11] also documented that, on intraseasonal timescale, the MJO effectively contributes to a considerable fraction of the total rainfall during January-May season over southeastern Amazon and NEB. More recently, Mo et al. [32] examined the influence of the MJO on Pan America during December-March and JuneSeptember for the period 1979-2001. Analyzing the evolution of the MJO cycle, they showed that in South America, the largest influence was found over northeastern Brazil during December-March.

Although these studies greatly contributed to improve the understanding of the MJO's influence over the South America, none of them focused specifically over NEB, or evaluated the MJO impact at individual station level. Even though a MJO signal may be difficult to detect at local scale, such information could be important for municipalities under water stress. Here, we introduce a study of the MJO's influence on the Seridó region, and we based our investigation on daily rainfall from 17 raingauge data over 30-year period. More specifically, we investigate the MJO signal at individual stations located in Seridó for each phase of the MJO's life cycle. This article is organized as follows. Data and methods are described in Section 2. The MJO signal on intraseasonal rainfall for each station in Seridó is discussed in Section 3. Then, a summary and final remarks of our work are provided in the final section.

\section{Data and Methods}

\subsection{Data}

The primary data used in this study were the time series of daily rainfall totals from raingauge records of the Rio Grande do Norte State, Northeast Brazil, provided by the Empresa Brasileira de Pesquisa Agropecuária do Rio Grande do Norte (EMPARN), for a 30-year period from 1 January-31 December, 1981-2010. According to the Brazilian Ministry of Agrarian Development [Ministério do Desenvolvimento Agrário (MDA); www.mda.gov.br], the Seridó/RN is divided into 25 municipalities, covering an area of $10,954.50 \mathrm{Km}^{2}$ (about $20.45 \%$ of the Rio Grande do Norte state) and has a population of around 295,700 inhabitants. In this study we selected a sub-set of 17 stations located in the Seridó/RN region (see frame on the right side in Figure 1 for location), following the geographical division of the Brazilian Institute of Geography and Statistics [Instituto Brasileiro de Geografia e Estatística (IBGE)]. A quality control has been previously conducted by the EMPARN and all the records have no missing data.

As shown in Table 1, the Seridó exhibits large spatial variability, with mean annual totals ranging between $480-800 \mathrm{~mm} /$ year. Our analysis focuses on February-May (FMAM), which is the region's main rainy season, corresponding between $70 \%-78 \%$ of the mean annual total. For the sake of simplicity, the stations were grouped into the Western Seridó and Eastern Seridó (according to IBGE). The Eastern Seridó area corresponds to the highlands on the western border of the Borborema Plateau, with its highest point $(807 \mathrm{~m})$ located in the Serra das Queimadas, in the Equador municipality. The topography decreases to the west, where the depressions of the rivers Seridó and Piranhas-Açu are located, with altitudes ranging between $50-200 \mathrm{~m}$.

The MJO index developed by Jones and Carvalho [16] (henceforth JCMi) was used to define and investigate the MJO influence on intraseasonal rainfall. The JCMi was derived from combined empirical orthogonal function (EOF) analysis of equatorially daily averaged $\left(15^{\circ} \mathrm{S}-15^{\circ} \mathrm{N}\right)$ band-filtered anomalies (20 - 200 days) of zonal wind components at $850-\mathrm{hPa}$ and $200-\mathrm{hPa}$, and constructed as follows. The seasonal cycle and trend were removed before applying the filtering procedure. The phase diagram of the first two normalized principal components (PC1, PC2) was used to identify MJO events according to four criteria: 1) the phase angle between PC1 and PC2 is required to systematically rotate counterclockwise to ensure the eastward propagation of the oscillation at least to the Maritime Continent (phase 5); 2) the amplitude $\left(\sqrt{\mathrm{PC}^{2}+\mathrm{PC}^{2}}\right)$ should be always 
larger than 0.35 ; 3 ) the mean amplitude during the event larger than 0.9 ; and, the entire duration of the event should be between 30 and 90 days. Composites of band-filtered outgoing longwave radiation (OLR) anomalies were used to characterize the convective anomalies associated with each of the MJO.

Jones [33] and Jones and Carvalho [34] [35], also used these same criteria, which are comparable to the criteria adopted by Matthews [36] [37]. The JCMi was available as daily time series, divided into 9 phases: phase 0 represents quiescent days (or MJO inactive). Phases 8 - 1 correspond to the period when the MJO's active center is over the Western Hemisphere and Africa. In phases 2 - 3, the convective center is in the Indian Ocean; then in phases 4 - 5 the convective envelope is in the Maritime Continent, and during phases 6 - 7 its convective center is in the Western Pacific Ocean.

\subsection{Methods}

Daily rainfall anomalies for each station were calculated by removing the 30-year daily climatology. Intraseasonal anomalies were obtained by bandpass filtering the time series of daily anomalies (1 January-31 December, 1981-2010) in frequency domain (20 - 90 days) by applying Fast Fourier Transform (FFT). The composite MJO rainfall signal at each station was obtained by averaging the intraseasonal anomalies over days that fell in each phase of the MJO during the FMAM rainy season. The statistical significance of the composites was assessed through a two-tailed Student's t-test at 5\% significance level against the null hypothesis that the composite was equivalent to the climatological mean (that is, zero anomaly). All the significance tests were computed independently at each individual station.

\section{The MJ0 Cycle in Daily Station Rainfall}

To examine the influence of the MJO on rainfall in the semiarid Seridó/RN we averaged intraseasonal rainfall anomalies at each station for the eight phases of the MJO. During FMAM 1981-2010, we found between 49 (phase 1) and 55 (phase 6) blocks of days (or "events"). For instance, for MJO phase 2 there were 50 events (2428 March 1981, 8-11 May 1981 ..., 18-20 March 2010, 4-6 May 2010). The composite MJO rainfall signals for each station are shown in Figure 3. If the rainfall anomaly at a particular station was statistically significant in a particular MJO phase, then a larger symbol was plotted on that phase.

During phases 1 - 3 the majority of stations showed enhanced rainfall. Maximum positive anomalies occurred in phase 2, where 13 out of the 17 stations showed statistically significant anomalies (between $0.9-1.9 \mathrm{~mm} /$ day). Significant positive anomalies are also found at 7 stations in phase 3 (between $1.1-1.7 \mathrm{~mm} /$ day). During phases 5 - 6 all stations showed suppressed rainfall. Statistically significant negative anomalies occurred at 12 stations in phase 5 (between $0.8-1.7 \mathrm{~mm} /$ day), and 10 stations in phase 6 (between $0.9-1.8 \mathrm{~mm} / \mathrm{h}$ ). Comparatively, stations located in the Western Seridó showed the absolute magnitude of rainfall anomalies slightly greater than those in the Eastern Seridó. Three stations did not show any statistically significant rainfall anomalies: Equador, Jardim de Piranhas and Santana do Seridó. Possibly, this may be related to raingauge exposure and local micrometeorological conditions, since raingauge measurements are influenced by factors such as instrument placement, and the topographic (ridge top, valley, etc.) and environmental (urban, suburban, rural, etc.) settings.

The results showed that the stations exhibited a similar anomaly pattern. Notice that there is a clear MJO signal in all the individual stations throughout the MJO cycle. The rainfall increased by about $30 \%$ in phase 2 and decreased by about $25 \%$ in phase 5 relative to the climatological mean for the whole Seridó/RN. Combining the MJO signals for wet phases 2 - 3 and dry phases 5 - 6, the difference represented about $50 \%-150 \%$ modulation of the mean rainfall considering all stations.

\section{Summary and Final Remarks}

Previous work on the MJO influence over tropical Brazil has been based only on gridded station rainfall data. Here, we hypothesize that the MJO effect on daily rainfall over the semiarid Seridó/RN in NEB could be felt at the local station level. We composited the MJO rainfall signal for each station during the region's main rainy season (FMAM). Each station composite was obtained averaging the rainfall anomalies over the contemporaneous (i.e., with zero lag) days that fell in each of the eight MJO phases, considering a 30-year period (1981-2010). Our results showed that the rainfall patterns in the Seridó undergo substantial changes (from enhancement to suppression) as the convective center of the MJO propagates eastward. Considering a 5\% significance level, the maximum positive rainfall anomalies occurred in phase 3 (or occasionally in phase 3) 


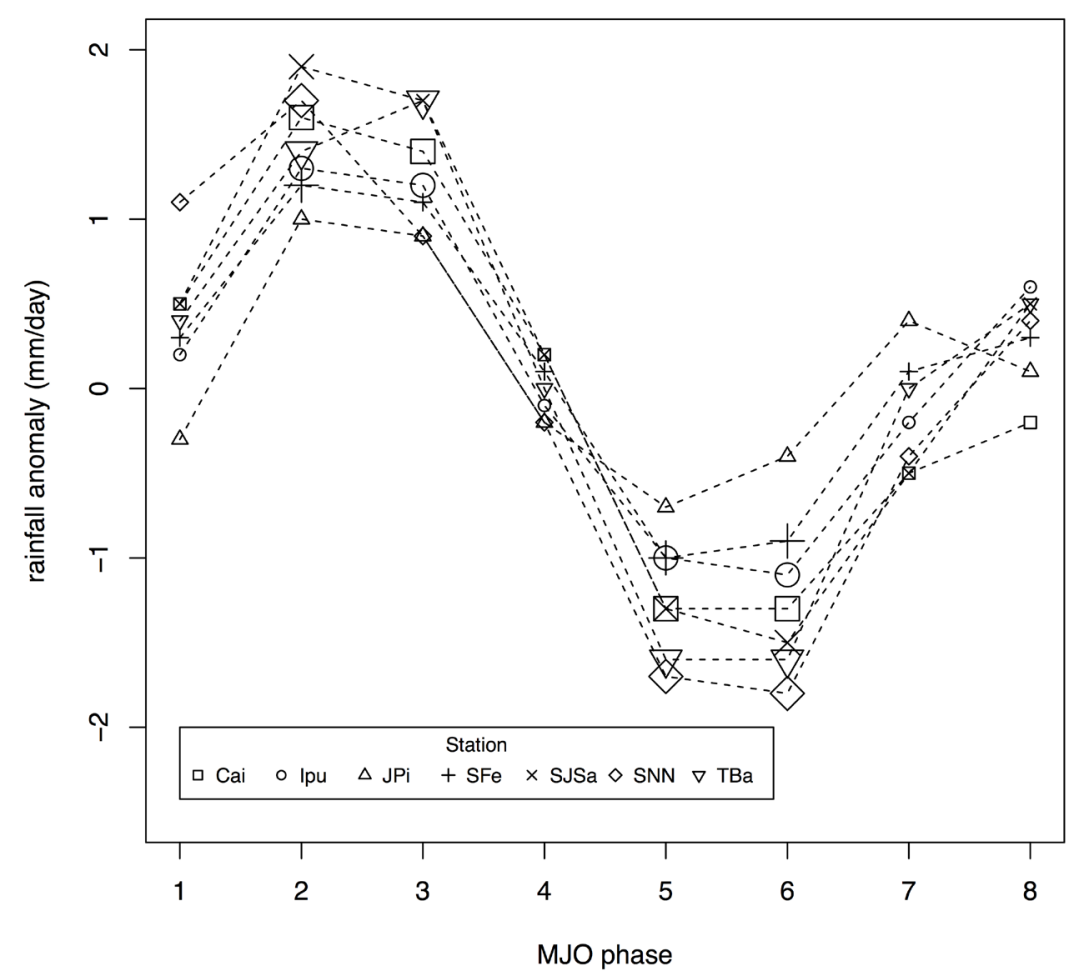

(a)

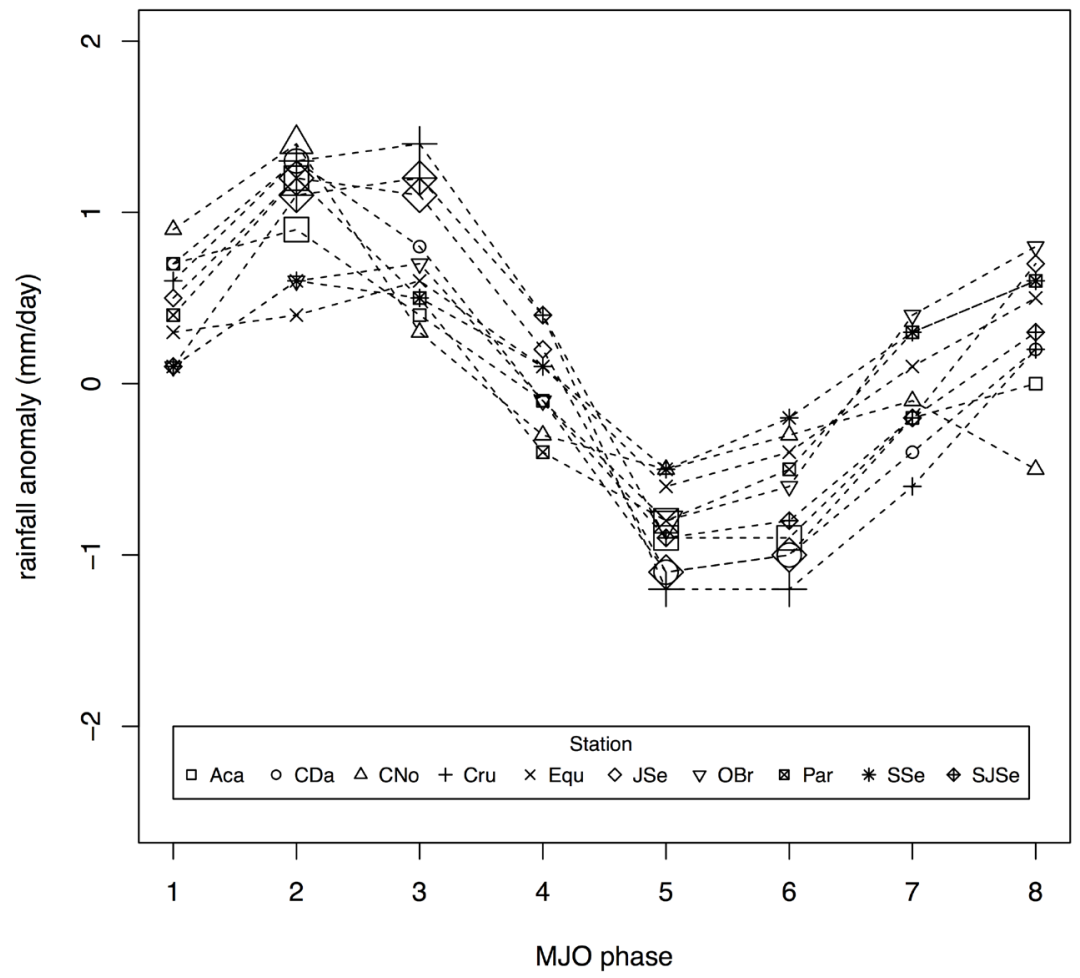

(b)

Figure 3. MJO cycle of rainfall anomaly (mm/day) for 17 stations in the Seridó/RN during FebruaryMay 1981-2010: (a) Western Seridó area; (b) Eastern Seridó area. Where a particular data point is statistically significant at the $5 \%$ significance level, a larger symbol is plotted. Station codes are in the legend (see Table 1 for station names). 
when the MJO's active convection was over the Indian Ocean, whereas the maximum negative anomalies occurred in phase 5 (or occasionally in phase 6), when its convection was passing through the Maritime Continent/Western Pacific Ocean. The typical difference between the wet phase 2 and dry phase 5 represented at least $50 \%$ modulation of the daily mean rainfall in 13 out of the 17 stations.

As stated in the introduction, in vulnerable semiarid regions, such as NEB, land degradation and droughts have negative impact on the quantity, quality and availability of water resources resulting in water scarcity. Moreover, prolonged breaks or extreme rainfall events during the rainy season can disrupt several sectors of society, such as agriculture, leading to devastating socio-economic consequences. Hence, knowing when wet and dry MJO phases may occur over the region could complement regional weather and short-term seasonal forecasts by combining this information with the MJO monitoring and forecast provided by some agencies (e.g., www.cpc.ncep.noaa.gov/products/precip/CWlink/MJO/mjo.shtml). These preliminary results for a smallscale study area have motivated our ongoing investigation of the MJO's modulation of rainfall over the entire NEB. We are combining multiple raingauge datasets in the analysis to evaluate the spatial extent of the rainfall signal at station level, whether there is a seasonal variation, and also the MJO-related changes in convection and circulation over the region.

\section{Acknowledgements}

The rainfall data were provided by the EMPARN. We thank Dr. Charles Jones for providing the MJO index, and Dr. Rodrigo J. Bombardi for providing some programming routines. We also thank the two anonymous reviewers for their comments and suggestions. Cati E. A. Valadão was supported by the Coordenação de Aperfeiçoamento de Pessoal de Nível Superior (CAPES) PhD scholarships (REUNI, DS and BEX 9108/12-2).

\section{References}

[1] MMA (2004) National Action Program to Combat Desertification and Mitigate the Effects of Drought: Pan-Brazil. Environment Ministry, Water Resources Secretariat, Tech. Rep. http://www.unccd.int/ActionProgrammes/brazil-eng2004.pdf

[2] Madden, R.A. and Julian, P.R. (1971) Detection of a 40-50 Day Oscillation in the Zonal Wind in the Tropical Pacific. Journal of the Atmospheric Sciences, 28, 702-708. http://dx.doi.org/10.1175/1520-0469(1971)028<0702:DOADOI>2.0.CO;2

[3] Madden, R.A. and Julian, P.R. (1972) Description of Global-Scale Circulation Cells in the Tropics with a 40-50 Day Period. Journal of the Atmospheric Sciences, 29, 1109-1123. http://dx.doi.org/10.1175/1520-0469(1972)029<1109:DOGSCC >2.0.CO;2

[4] Madden, R.A. and Julian, P.R. (1994) Observations of the 40-50-Day Tropical Oscillation: A Review. Monthly Weather Review, 122, 814-837.

[5] Zhang, C. (2005) Madden-Julian Oscillation. Reviews of Geophysics, 43, n/a. http://dx.doi.org/10.1029/2004rg000158

[6] Carvalho, L.M.V., Jones, C. and Liebmann, B. (2002) Extreme Precipitation Events in Southeastern South America and Large-Scale Convective Patterns in the South Atlantic Convergence Zone. Journal of Climate, 15, 2377-2394. http://dx.doi.org/10.1175/1520-0442(2002)015<2377:EPEISS >2.0.CO;2

[7] (2004) The South Atlantic Convergence Zone: Intensity, Form, Persistence, and Relationships with Intraseasonal to Interannual Activity and Extreme Rainfall. Journal of Climate, 17, 88-108. http://dx.doi.org/10.1175/1520-0442(2004)017<0088:TSACZI >2.0.CO;2

[8] Liebmann, B., Vera, C.S., Carvalho, L.M.V., Camilloni, I.A., Hoerling, M.P., Allured, D., Barros, V.R., Bez, J. and Bidegain, M. (2004) An Observed Trend in Central South American Precipitation. Journal of Climate, 17, 4357-4367. http://dx.doi.org/10.1175/3205.1

[9] Muza, M.N., Carvalho, L.M.V., Jones, C. and Liebmann, B. (2009) Intraseasonal and Interannual Variability of Extreme Dry and Wet Events over Southeastern South America and the Subtropical Atlantic during Austral Summer. Journal of Climate, 22, 1682-1699. http://dx.doi.org/10.1175/2008JCLI2257.1

[10] Nogus-Paegle, J.N., Byerle, L.A. and Mo, K.C. (2000) Intraseasonal Modulation of South American Summer Precipitation. Monthly Weather Review, 128, 837-850. http://dx.doi.org/10.1175/1520-0493(2000)128<0837:IMOSAS>2.0.CO;2

[11] Souza, E.B. and Ambrizzi, T. (2006) Modulation of the Intraseasonal Rainfall over Tropical Brazil by the Madden-Julian Oscillation. International Journal of Climatology, 26, 1759-1776. http://dx.doi.org/10.1002/joc.1331

[12] Pohl, B. and Camberlin, P. (2006) Influence of the Madden-Julian Oscillation on East African Rainfall. I: Intraseasonal 
Variability and Regional Dependency. Quarterly Journal of the Royal Meteorological Society, 132, 2521-2539. http://dx.doi.org/10.1256/qi.05.104

[13] Pohl, B. and Camberlin, P. (2006) Influence of the Madden-Julian Oscillation on East African rainfall: II. March-May Season Extremes and Interannual Variability. Quarterly Journal of the Royal Meteorological Society, 132, 2541-2558. http://dx.doi.org/10.1256/qj.05.223

[14] Mo, K.C. and Higgins, R.W. (1998) Tropical Convection and Precipitation Regimes in the Western United States. Journal of Climate, 11, 2404-2423. http://dx.doi.org/10.1175/1520-0442(1998)011<2404:TCAPRI>2.0.CO;2

[15] Jones, C. (2000) Occurrence of Extreme Precipitation Events in California and Relationships with the Madden-Julian Oscillation. Journal of Climate, 13, 3576-3587. http://dx.doi.org/10.1175/1520-0442(2000)013<3576:OOEPEI>2.0.CO;2

[16] Jones, C. and Carvalho, L.M.V. (2012) Spatial-Intensity Variations in Extreme Precipitation in the Contiguous United States and the Madden-Julian Oscillation. Journal of Climate, 25, 4898-4913. http://dx.doi.org/10.1175/JCLI-D-11-00278.1

[17] Mo, K.C. and Higgins, R.W. (1998) Tropical Influences on California Precipitation. Journal of Climate, 11, $412-430$. http://dx.doi.org/10.1175/1520-0442(1998)011<0412:TIOCP >2.0.CO;2

[18] Zhou, S., Heureux, M.L., Weaver, S. and Kumar, A. (2011) A Composite Study of the MJO Influence on the Surface Air Temperature and Precipitation over the Continental United States. Climate Dynamics, 38, 1459-1471. http://dx.doi.org/10.1007/s00382-011-1001-9

[19] Lin, H., Brunet, G. and Mo, R. (2010) Impact of the Madden-Julian Oscillation on Wintertime Precipitation in Canada. Monthly Weather Review, 138, 3822-3839. http://dx.doi.org/10.1175/2010MWR3363.1

[20] Wheeler, M.C., Hendon, H.H., Cleland, S., Meinke, H. and Donald, A. (2009) Impacts of the Madden-Julian Oscillation on Australian Rainfall and Circulation. Journal of Climate, 22, 1482-1498. http://dx.doi.org/10.1175/2008JCLI2595.1

[21] Kanamori, H., Yasunari, T. and Kuraji, K. (2013) Modulation of the Diurnal Cycle of Rainfall Associated with the MJO Observed by a Dense Hourly Rain Gauge Network at Sarawak, Borneo. Journal of Climate, 26, 4858-4875. http://dx.doi.org/10.1175/JCLI-D-12-00158.1

[22] Peatman, S.C., Matthews, A.J. and Stevens, D.P. (2013) Propagation of the Madden-Julian Oscillation through the Maritime Continent and Scale Interaction with the Diurnal Cycle of Precipitation. Quarterly Journal of the Royal Meteorological Society, 140, 814-825. http://dx.doi.org/10.1002/qj.2161

[23] Jia, X., Chen, L., Ren, F. and Li, C. (2011) Impacts of the MJO on Winter Rainfall and Circulation in China. Advances in Atmospheric Sciences, 28, 521-533. http://dx.doi.org/10.1007/s00376-010-9118-Z

[24] Zhang, L., Wang, B. and Zeng, Q. (2009) Impact of the Madden-Julian Oscillation on Summer Rainfall in Southeast China. Journal of Climate, 22, 201-216. http://dx.doi.org/10.1175/2008JCLI1959.1

[25] Hartmann, D.L. and Michelsen, M.L. (1989) Intraseasonal Periodicities in Indian Rainfall. Journal of the Atmospheric Sciences, 46, 2838-2862. http://dx.doi.org/10.1175/1520-0469(1989)046<2838:IPIIR>2.0.CO;2

[26] Hendon, H.H. and Liebmann, B. (1990) A Composite Study of Onset of the Australian Summer Monsoon. Journal of the Atmospheric Sciences, 47, 2227-2240. http://dx.doi.org/10.1175/1520-0469(1990)047<2227:ACSOOO>2.0.CO;2

[27] Jones, C. and Carvalho, L.M.V. (2002) Active and Break Phases in the South American Monsoon System. Journal of Climate, 15, 905-914. http://dx.doi.org/10.1175/1520-0442(2002)015<0905:AABPIT>2.0.CO;2

[28] Matthews, A.J. (2004) Atmospheric Response to Observed Intraseasonal Tropical Sea Surface Temperature Anomalies. Geophysical Research Letters, 31. http://dx.doi.org/10.1029/2004gl020474

[29] Pai, D., Bhate, J., Sreejith, O. and Hatwar, H. (2009) Impact of MJO on the Intraseasonal Variation of Summer Monsoon Rainfall over India. Climate Dynamics, 36, 41-55. http://dx.doi.org/10.1007/s00382-009-0634-4

[30] Pohl, B., Richard, Y. and Fauchereau, N. (2007) Influence of the Madden-Julian Oscillation on Southern African Summer Rainfall. Journal of Climate, 20, 4227-4242. http://dx.doi.org/10.1175/JCLI4231.1

[31] Souza, E.B., Kayano, M.T. and Ambrizzi, T. (2005) Intraseasonal and Submonthly Variability over the Eastern Amazon and Northeast Brazil during the Autumn Rainy Season. Theoretical and Applied Climatology, 81, 177-191. http://dx.doi.org/10.1007/s00704-004-0081-4

[32] Mo, K.C., Jones, C. and Nogues-Paegle, J. (2012) Pan America. In: Lau, K.M. and Waliser, D.E., Eds., Intraseasonal Variability in the Atmosphere-Ocean Climate System, 2nd Edition, Springer-Verlag, Berlin, 613.

[33] Jones, C. (2009) A Homogeneous Stochastic Model of the Madden-Julian Oscillation. Journal of Climate, 22, 32703288. http://dx.doi.org/10.1175/2008JCLI2609.1

[34] Jones, C. and Carvalho, L.M.V. (2011) Will Global Warming Modify the Activity of the Madden-Julian Oscillation? Quarterly Journal of the Royal Meteorological Society, 137, 544-552. http://dx.doi.org/10.1002/qj.765 
[35] Jones, C. and Carvalho, L.M. (2011) Stochastic Simulations of the Madden-Julian Oscillation Activity. Climate Dynamics, 36, 229-246. http://dx.doi.org/10.1007/s00382-009-0660-2

[36] Matthews, A.J. (2000) Propagation Mechanisms for the Madden-Julian Oscillation. Quarterly Journal of the Royal Meteorological Society, 126, 2637-2651. http://dx.doi.org/10.1002/qi.49712656902

[37] Matthews, A.J. (2008) Primary and Successive Events in the Madden-Julian Oscillation. Quarterly Journal of the Royal Meteorological Society, 134, 439-453. http://dx.doi.org/10.1002/qj.224 